\title{
Increase of seeding material quality of agrarian crops by the pneumatic electric separator
}

\author{
Urszula Malaga-Toboła ${ }^{1, *}$ Stepan Kovalyshyn ${ }^{2}$, Viktor Dadak $^{2}$ and Ivan Horodetskyy ${ }^{2}$ \\ ${ }^{1}$ Faculty of Production and Energy Engineering, University of Agriculture in Krakow, Balicka 116B, \\ 30-149 Krakow, Poland \\ ${ }^{2}$ Faculty of Mechanics and Power Engineering, Lviv National Agrarian University, 80381, Lviv, \\ Ukraine
}

\begin{abstract}
A detailed analysis of technical means and methods of seeds separation, as well as the research results of domestic and foreign authors, have proved that one of the perspective methods for getting of high quality seed material is the pneumatic and electric separation. The analysis of research works and the modern technical level of pneumatic separators showed that insufficient attention was paid to the study of aerodynamic separation of small-seed crops, especially, cereal grasses. By the conditions of separation in a vertical pneumatic channel the cereal crops change the area of the midlength section as to the air flow forces, and the probability was increased of getting of seeds with germs to a biologically defective seed without germs. To increase the quality of pneumatic separation one can by the selective orientation of seeds in mixture with longer axis perpendicularly to the flow of air. It is possible to achieve these conditions by the additional force action on seeds (as particles). The response of this force action could be different for a healthy seeds (with germs) and for a non-viable (without embryo) or a weed seed. Such a force effect on the particles of small-seed crop mixtures can be realized by creating of a homogeneous electric field in a separation channel. This requires a theoretical and experimental study of force action on particles during the process of separation, also justification of parameters and operating modes of the pneumatic electric separator. This study is the preconditions for design improvement of the pneumatic electric separator.
\end{abstract}

\section{Introduction}

The ever-increasing of Earth's population needs more of food. One of the main food products is bread, the basis of which is cereals. The most important cereal crops are wheat, rye, barley, oats, and buckwheat. To provide the necessary amount of cereal crops man must increase crops areas, yield of crops which ultimately are determined by the quantity and quality of seed material, levels of technologies, techniques, mineral fertilization, etc. [1, 2].

*Corresponding author: umalagatobola@gmail.com 
In the structure of agricultural lands of Ukraine are about 5 million hectares or $20 \%$ cultivated field areas of agricultural crops, which are considered as small-seeded. They have weight less than 5 grams per 1 thousand of seeds [19]. This are mainly vegetable, oilseed crops and majority of forage grasses.

High yields of agricultural crop are not possible without a sufficient quantity of high quality seed materials. After harvesting preparing of seed material is important operation for seed quality and the equipment for seed preparation processes (treatment or processing) need significant improvement [20]. The problem of preparing of seed material from small seed crops is in technical equipment. In many cases it does not provide qualitative cleaning of seed mixture. As a result during separation a large number of conditioned seeds (of good quality) were get into the waste. In other hand it was impossible to separate small seed of culture crops from weeds seed.

\subsection{Analysis of studies and publications}

Seed cleaning machines separate seed mixture by means of the air grading sieve and pocket cleaner or friction working bodies. The physical and mechanical properties of the seeds are used as the indication of seed separation. But seeds of weed and of small-seed mixtures cultural crops do not have a dominant feature of divisibility, because they have almost the same size, form, friction coefficient. As a result, nowadays there are no sufficiently effective means for seed mixture clearing of alfalfa, clover, timothy, pasture ryegrass, carrots, parsley, dill, onion, spring and winter rape, flax, etc._The loss of conditioned (full value) seeds during its clearing is from 20 to $50 \%$ [21]. Increase of purified seeds output, for example, of perennial grasses, by only $1 \%$ on a nationwide scale is equivalent to an expansion of crops by more than 20 thousand ha [22].

In [3-5] research works have been shown that pre-sowing processing of seed material of cereal crops by an electrostatic field leads to efficient separation of weed seed and crushed grains from healthy and full value seed. In addition to cleaning, the influence of the electrostatic field on grain increases the efficiency of cells functioning of grain by improving the water (carrying) capacity through cell membrane. Water penetration into the cell is a trigger for the initiation of hydrolytic enzymes, in particular of amylase [6]. This allows more effectively realize the genetic potential of the grain seeds, more steadfastly withstand to the environmental factors on the sowing grain (insufficient moisture, temperature drop etc) $[5,6]$.

Accordingly to intensify the crop production in agricultural practices the different methods were tested as to pre-sowing treatment of seed of grain and vegetable crop, especially the processing by electrostatic [3-5, 7] or magnetic [8] fields, ultraviolet radiation [10], infrared [11] or laser radiation of different wavelengths [11-13], processing of high and ultrahigh frequencies [6, 15-17], ultrasound processing [18].

Because nowadays there is a need to develop and improve machines which not only take into account the physical and mechanical properties of seeds, but also biological. To solve the problems during separating the seed material of small-seed mixtures the electric field could be used as additional working process. According to study of [23], authors propose such machine as pneumatic separator, which can combine the electrical and aerodynamic properties in order to separate the perennial grasses mixture [24].

The main task of the research work was to study the influence of the regulated parameters of the separation process of small-seed mixtures of cereal grasses on the quality of the seed material. 


\section{Material and methods}

The aim of the multifactorial experiment was to establish the laws of influence of the regulated parameters of the separation process, namely, the values of the seed feed $\mathrm{Q}, \mathrm{kg} \cdot \mathrm{h}^{-}$ 1 , the air flow velocity in vertical separation channel $\mathrm{Vn}, \mathrm{m} \cdot \mathrm{sec}^{-1}$ and the electric field intensity $\mathrm{E}, \mathrm{kV} \cdot \mathrm{cm}^{-1}$ in the separation zone on qualitative indicators of the seed material, expressed by percentage K, \% of quality seeds (with the embryo) in the seed material. The coded values and variation levels of the studied parameters are given in table 1.

Table 1. Results of coding of research factors

\begin{tabular}{|c|c|c|c|c|c|c|c|c|c|}
\hline \multirow{3}{*}{$\begin{array}{l}\text { Factors and units of } \\
\text { measurement }\end{array}$} & \multirow{3}{*}{ 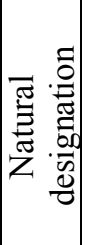 } & \multirow{3}{*}{ 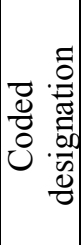 } & \multirow{3}{*}{ 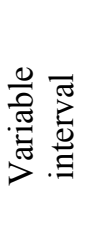 } & \multicolumn{6}{|c|}{ Levels of factors variation } \\
\hline & & & & \multicolumn{3}{|c|}{ Natural } & \multicolumn{3}{|c|}{ Coded } \\
\hline & & & & 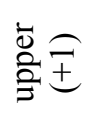 & $\begin{array}{c}\underset{\Xi}{\Xi} \\
\underset{\Xi}{\Xi}\end{array}$ & $\stackrel{\dot{0}}{\overrightarrow{0}}$ & 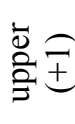 & 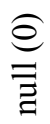 & $\stackrel{\overline{0}}{\widehat{\Xi}}$ \\
\hline Seeds feed $Q, \mathrm{~kg} / \mathrm{h}$ & $X_{1}$ & $x_{1}$ & 1 & 4 & 3 & 2 & +1 & 0 & -1 \\
\hline $\begin{array}{l}\text { Air flow velocity } V n \text {, } \\
m / s e c\end{array}$ & $X_{2}$ & $x_{2}$ & 0,5 & 5,5 & 5 & 4,5 & +1 & 0 & -1 \\
\hline $\begin{array}{l}\text { Electric field intensity } \\
E, \mathrm{kV} / \mathrm{cm}\end{array}$ & $X_{3}$ & $x_{3}$ & 0,15 & 0,92 & 0,77 & 0,62 & +1 & 0 & -1 \\
\hline
\end{tabular}

To find the coefficients of a polynomial, we used a three-level plan of the second order of Box-Benkin (Tab. 1). To determine the coefficients of a polynomial under the terms of this plan, a multivariate experiment of fifteen experiments was realized. The matrix of the experiment is shown in table 2.

During the multivariate experiment, the content of biologically defective non-quality seed without embryos was the controlled parameter in the studied material. The number of defected seeds was determined by X-ray analysis on an Faxitron-X-ray device (Fig.1).

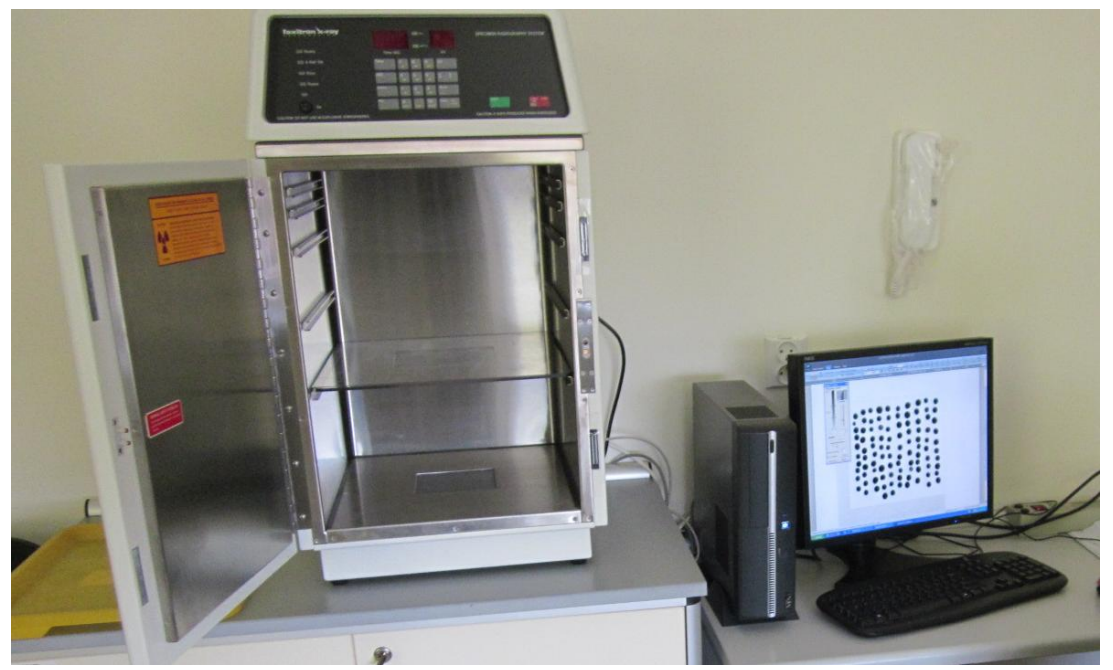

Fig. 1. Faxitron X-ray device 
Experiments were carried out with using the seeds of ryegrass "Osyp" variety of the III-rd reproduction with a moisture content of $9 \%$. In the study process the values of the regulated parameters of the separation and cleaning process were determined according to the experiment plan.

\section{Results and discussion}

The seed mixture was fed directly to the separation canal, with the help of a vibration dispenser, which have ensured an even initial velocity of the individual seeds. Samples of seeds were taken from the cleaned seed material in order to determine the quantity of seeds without embryos in mixture. The experiment was repeated three times at each feeding, air velocity in the channel and electric field strength. The results of the research are presented in table 2.

Table 2. The results of a multifactorial experiment

\begin{tabular}{|c|c|c|c|c|c|c|c|}
\hline \multirow{2}{*}{$№$} & \multicolumn{2}{|c|}{ Value of coded factors } & \multicolumn{2}{c|}{ X-ray findings (\% of seed with embryo) } & \multirow{2}{*}{$\begin{array}{c}\text { Average } \\
\text { value }\end{array}$} \\
\cline { 2 - 8 } & $x_{1}$ & $x_{2}$ & $x_{3}$ & replication 1 & replication 2 & replication 3 & \\
\hline 1 & 2 & 3 & 4 & 5 & 6 & 7 & 8 \\
\hline $\mathbf{1}$ & -1 & -1 & 0 & 90 & 89 & 88 & 89 \\
\hline $\mathbf{2}$ & 1 & -1 & 0 & 86 & 88 & 90 & 88 \\
\hline $\mathbf{3}$ & -1 & 1 & 0 & 96 & 95 & 94 & 95 \\
\hline $\mathbf{4}$ & 1 & 1 & 0 & 80 & 82 & 84 & 82 \\
\hline $\mathbf{5}$ & -1 & 0 & -1 & 86 & 87 & 88 & 87 \\
\hline $\mathbf{6}$ & 1 & 0 & -1 & 88 & 90 & 92 & 90 \\
\hline $\mathbf{7}$ & -1 & 0 & 1 & 96 & 96 & 96 & 96 \\
\hline 1 & 2 & 3 & 4 & 5 & 6 & 7 & 8 \\
\hline $\mathbf{8}$ & 1 & 0 & 1 & 89 & 88 & 90 & 89 \\
\hline $\mathbf{9}$ & 0 & -1 & -1 & 90 & 91 & 89 & 91 \\
\hline $\mathbf{1 0}$ & 0 & 1 & -1 & 93 & 92 & 92 & 92 \\
\hline $\mathbf{1 1}$ & 0 & -1 & 1 & 94 & 88 & 88 & 90 \\
\hline $\mathbf{1 2}$ & 0 & 1 & 1 & 95 & 92 & 92 & 93 \\
\hline $\mathbf{1 3}$ & 0 & 0 & 0 & 88 & 89 & 90 & 89 \\
\hline $\mathbf{1 4}$ & 0 & 0 & 0 & 91 & 93 & 89 & 91 \\
\hline $\mathbf{1 5}$ & 0 & 0 & 0 & 90 & 89 & 91 & 90 \\
\hline
\end{tabular}

The reproducibility of the experimental results have been verified by the Cochran criterion according to which the hypothesis of the reproducibility of the experiments was taken if the estimated value $G_{p}$ of the criterion was less than its table value: 


$$
G_{p} \leq G_{T}\left(0,05 ; n ; f_{i}\right)
$$

where:

0,05 - 5-th percent level of significance,

$n$ - total number of independent variances (number of experiments),

$f_{i}-$ number of degrees of freedom of each of them.

The calculated value of Cochran criterion was $G_{p}=0.31$, which is smaller than the table value $\mathrm{G}_{\mathrm{t}}=0.47$. This indicates the reproducibility of fulfilled experimental study.

After processing of the results of a multivariate experiment in the Statistica 8.0 software the regression equation was got. This function describes the dependence of the content of qualitative seeds in the sowing material of pasture ryegrass from the regulated parameters of the separation process:

- in the Coded designation:

$$
K=89,23-2,25 x_{1}+0,5 x_{2}+1 x_{3}-3 x_{1} x_{2}-2,5 x_{1} x_{3}+0,5 x_{2} x_{3}-1,385 x_{1}^{2}-1,154 x_{2}^{2}+1,77 x_{3}^{2}
$$

- in the Natural designation:

$K=49,29+46,12 Q+14,02 V-114,41 E-1,38 Q^{2}-0,615 V^{2}+78,62 E^{2}-6 Q V-16,6 Q E+6,66 V E$

To establish the law of influence of the regulated parameters of the separation process by equation 2 the surfaces of the response were built (Fig. 2, 3 and 4).

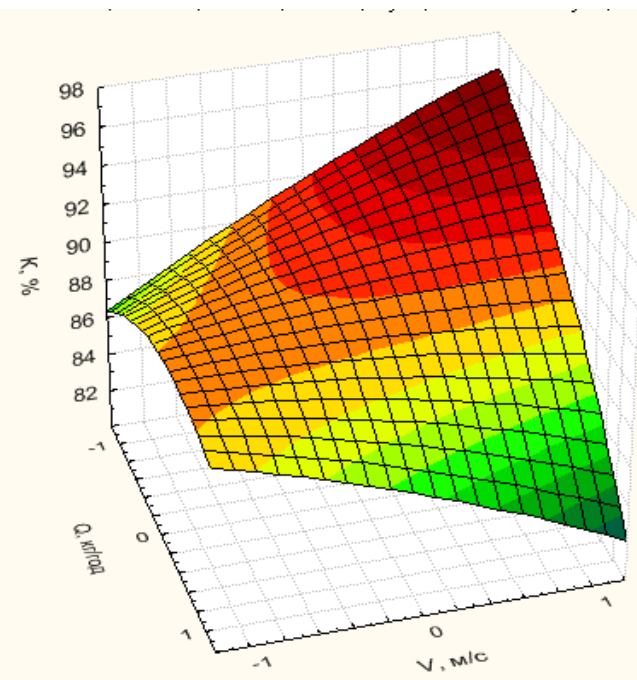

Fig. 2. The surface of the response of $K=f\left(V_{n}, Q\right)$

From the figure 2, we can see that the function is the maximum value by $Q=-1$, which in real value is $\mathrm{Q}=2 \mathrm{~kg} \cdot \mathrm{h}^{-1}$. The influence of parameter $\mathrm{V}$ under such conditions of separation was maximal by $\mathrm{V}=1$, or $\mathrm{V}=5,5 \mathrm{~m} \cdot \mathrm{sec}^{-1}$. Under such conditions, the number of the quality seeds is $\mathrm{K}=94-96 \%$. 


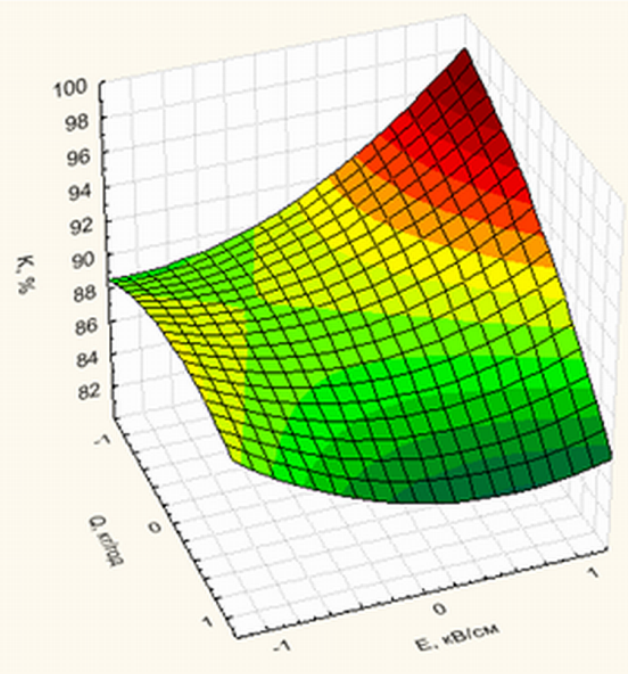

Fig. 3. The surface of the response $K=f(E, Q)$

The function of dependency of the quality seeds quantity is shown on figure 3 . This function has the maximum value by $\mathrm{Q}=-1$, which in real value is $\mathrm{Q}=2 \mathrm{~kg} \cdot \mathrm{h}^{-1}$ and $\mathrm{E}=1$, that is $\mathrm{E}=0,92 \mathrm{kV} \cdot \mathrm{cm}^{-1}$. With such operating mode of the cleaner separator, the content of quality seeds is $\mathrm{K}=96-98 \%$.

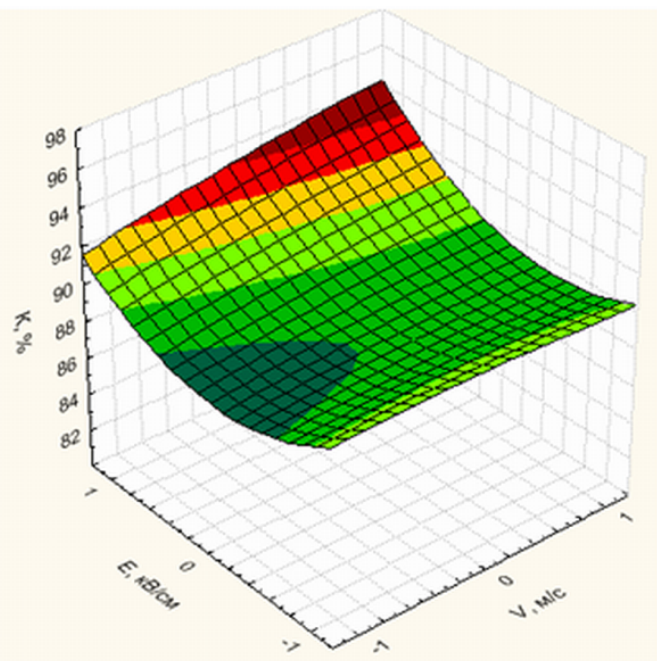

Fig. 4. The surface of the response $K=f\left(E, V_{n}\right)$

The function of $\mathrm{K}=\mathrm{f}(\mathrm{E}, \mathrm{Vp})$ has a maximum level at the maximum values of the regulated parameters of $\mathrm{E}=1$ and $\mathrm{V}=1$, which in real value is $\mathrm{E}=0,92 \mathrm{kV} \cdot \mathrm{cm}^{-1}$, and $\mathrm{Vp}=$ $5,5 \mathrm{~m} \cdot \mathrm{sec}^{-1}$. With such parameters of the separator, the content of quality seeds is $\mathrm{K}=92-$ $94 \%$. Such seed quality is appropriate to the requirements of the standard of DSTU 7160:2010 "Seeds of vegetable, melon, fodder and spice-aromatic crops. Varietal and sowing qualities. Technical specifications"[20]. 
The adequacy of the study results was checked according to the Fisher's criterion. It was of $\mathrm{F}=1,21$, which indicates the adequacy of the study results.

The analysis of the study results allowed to determine the optimal values of the adjustable parameters of the pneumatic electric separator, in which it is possible to obtain the highest quality of seed material. So, to ensure the maximum efficiency of separation of pasture ryegrass sowing material, it is necessary to maintain the velocity the airflow of $\mathrm{Vp}$ $=5,5 \mathrm{~m} \cdot \mathrm{sec}^{-1}$, the electrostatic field intensity in the separation channel of $\mathrm{E}=0,92 \mathrm{kV} \cdot \mathrm{cm}^{-1}$ and seed feed of $Q=2 \mathrm{~kg} \cdot \mathrm{h}^{-1}$.

\section{Conclusions}

1. The quality of the separation process of the pasture ryegrass seeds depends of the velocity of the air flow, the feed of the seed mixture and the strength (intensity) of the electrostatic field.

2. Determined optimal modes of operation of the separator at which the maximum quality of separation was achieved were: the feed of a seed mixture $Q=2 \mathrm{~kg} \cdot \mathrm{h}^{-1}$, the intensity of the electrostatic field in the separator channel $\mathrm{E}=0,92 \mathrm{kV} \cdot \mathrm{cm}^{-1}$ and the air flow velocity $\mathrm{Vp}=5,5 \mathrm{~m} \cdot \mathrm{s}^{-1}$.

3. The usage of proposed separator in the technological line of preparation of seeds of cereal grasses can significantly improve the quality of the sowing material.

\section{References}

1. M. Cupiał, Z. Kowalczyk, Res. Tren. in Agric. Eng. BIO Web Conf. 10 02002, 4, (2018).

2. X. Jiang, T. Min, Z. Chunqing, L Fade, Trans. of the Chin. Soc. of Agric. Eng., 29 23, 233-240, (2013)

3. V. Ciobanu, A. Visan, A. Paun, G. Bogdanof, 16th Int. Scien. Conf. on Eng. for Rur. Dev. Latvia Univ Agr, 1000-1005, (2017)

4. M. Gugała, A. Sikorska, P. Findura, K. Kapela, U. Malaga-Toboła, K. Zarzecka, Ł. Domański, App. Eco. and Env. Res., 17 2, 2779-2789, (2019).

5. S. Kovalyshyn, Int. Agrophys., 30 4, 545-550, (2016).

6. I.A. Yelovskaya, Z.E. Mazetz, I.V. Pushkina, V.A. Karpovich, Veszi BDPU, 1 3, 14-22, (2016).

7. D. Zare, A. Bakhshipour, G. Chen. Int. Agrophys., 274 , 491-494, (2013).

8. S.V. Verbitskaya, Diss. Cand. Tech. Scien., 05.20.02 / S.V. Verbitskaya. Zernograd, 181, (2001).

9. D. Luczycka, Publishing house of Wroclaw University of Envir. and Lif. Scien. (2009).

10. R. Vijay, R. Jain, K. Sharma, Int. Agrophys. 29 2, 239-246, (2015).

11. W. Woźniak, J. Niewczas, T. Kudra, Int. Agrophys., 13 2, 259-268, (1999).

12. E. Sacała. A. Demczuk, E. Grzyś, U. Prośba-Białczyk, H. Szajsner, Int. Agrophys., 26 3, 295-300, (2012).

13. S. Pietruszewski, S. Muszyński, A. Dziwulska, Int. Agrophys., 21 1, 95-100, (2007).

14. R. Koper, Z. Dygbata, Pat. 162598, Polska, MKU ${ }^{5}$ A01C1/06. Agric. Aca., 283494.12., (2006).

15. K.N. Shcherbakov, M. MESH,7, 26-29, (2002).

16. R.B. Goldman, Diss. Cand. Tech. Scien., 05.20.02. / R. B. Goldman. Krasnodar. 18, (2002) .

17. A.I. Chmil, K.O. Lazaruk, Pow. Eng and Aut., 4, 227-233, (2015). 
18. R.A Zubov, Diss. Cand. Tech. Scien., 05.20.02 / P.A. Zubov. Barnaul 20, (2017).

19. S. Kovalyshyn, O. Shvets, S. Grundas, J. Tys, Int. Agrophys., 27, 419-424, (2013).

20. Ukrainian State Standards. 2010. Seeds of plant species: vegetables, hippocastanaceae, fodder and intoxicating-aromatic. Varietal and sowing quality. Technical standard: DSTU 7160. Ukrain.

21. S. Kovalyshyn, V. Dadak, S. Konyk, Act. Tech. Agric. the Scien. J. for Agric. Eng., Nitra, Slovaca Universitas Agriculturae Nitriae, 4, 108-112, (2015).

22. S.Y. Kovalyshyn, V.O. Dadak, Bull. in of the Kharkiv Nat. Technic. Uni. of Agric. named after Petr Vaylenko, Tech. Sys. and Technol. of Animal Husbandry, 144, $225-$ 232, (2014).

23. A. Sumorek, W. Pietrzyk, Int. Agrophys., 13 4, 509-513, (1999).

24. M. Moya, P. Aguado, F. Ayuga, Int. Agrophys., 27 2, 181-193, (2013). 